\title{
Mudik Myth in The Baudrillard's Simulacra Perspective
}

\author{
Rima Agristina ${ }^{1 *}$, Leonnard Ong ${ }^{2}$ \\ ${ }^{12}$ Sekolah Tinggi Manajemen IPMI, DKI Jakarta 12750, Indonesia
}

\begin{abstract}
A B S T R A C T
The research aims to review literatures and discuss regarding the myths and simulacra of homecoming. The research conducted is normative research or study literature, using a variety of literature (a semiotic approach) that discusses regarding myths, simulacras and simulations. This semiotic approach is used with based on the idea that the notion of myth in this study using the understanding of myth according to Barthes's view of the myth as semiological system of the second order (simulacra) of Baudrillard. Homecoming can be understood as a need for social existence and human legitimacy. Re-growth of existence in a society carrying out homecoming can be done by understanding the characteristics of the homecoming perceived by society. This respect or social legitimacy is usually explained because of positive word of mouth for being an urbanity. By understanding the homecoming's character perceived by society, the need for existence through "mudik" can put into other activities so that people carry out to a more rational homecoming regularly. Because the research is in the from of literature and qualitative study, it is necessary to carry out further research on public perceptions regarding homecoming by considering cultural or ethnic factors, and also favorable behavioral intentions consisting of positive word of mouth.
\end{abstract}

ART ICLE INF O

Article History:

Received : 21-12-2020

Revised : 26-01-2021

Accepted : 09-02-2021

Published : 15-02-2021

Keywords:

Homecoming

Myth

Simulacra

Simulation

Word of Mouth

${ }^{*}$ Corresponding Author E-mail:

rima.agristina@ipmi.ac.id

Copyright (c) 2021 Authors. This is an open access article distributed under the Creative Commons Attribution License (CC-BY-SA 4.0) which permits use, distribution and reproduction in any medium, provided the original work is properly cited \& ShareAlike terms followed.

\section{INTRODUCTION}

Homecoming or mudik in Indonesia is something that always gets special attention from the public and government, as well as from the mass media. Homecoming based on the Indonesian Dictionary or KBBI (Kamus Besar Bahasa Indonesia) (Kemdikbud, 2020) means sailing or going to a hill (upstream, hinterland). Homecoming can also be interpreted as returning home or returning to village (Kemdikbud, 2020). Homecoming or mudik is done by the majority Indonesian society and the term seems to be a special term for activities back home which is specifically carried out in the month of Ramadan. Because it involves most of the Indonesian people, it causes various social 
problems, ranging from long queues, congestion on the road highway, to the fall of many casualties.

The number of travelers who died when home coming in the month of Ramadan 2019 recorded 132 victims 16 percent higher than in 2011), injured 97 people and 300 minory injured, out of 529 incidents in the Day-7 to Day+7 period of Lebaran (CNN Indonesia, 2019). Even though mudik always causes casualties, but it turns out that regardless of the number of victims falling because of going home, does not moderate the enthusiasm of the Indonesian people to remain carry out homecoming, especially in the month of Ramadan. Homecoming seems to have a strong urge in to carry it out though various obstacles confront.

Homecoming at this time in Indonesia no longer means going home to a village. Homecoming means new clothes, new motorbikes or cars, "new" money, long traffic jam, vacation, success, existence and many others. Thus the problems of the research were done are as follows. In the midst of the progress of civilization accompanied by society development of information and communication technology, travelers should be more intelligent and rational to be able to judge productive or not productive homecoming activities that they will carry out. With the passage of time and various socioeconomic changes, parents or other family members who live in their homecoming destination gradually disappear.

However, with all conditions and situations that have changed from the side of the travelers and from the point of view of the homecoming destination, this does not negate or reduce the flow of homecoming trips. As if there was a strong urge that cannot be controlled by travelers, as a habit that must be done, it cannot be abandoned although facing the risk of death. Thus, the homecoming trips and travellers number each year always increase.

The research problems mentioned above will be answered with an approach of mudik as a myth using the viewpoint of Barthes (1972a) in the simulacra which is based on the views of Baudrillard (Lane, 2000). Thus, the research aims to review literatures and discuss regarding the myths and simulacra of homecoming.

\section{LITERATURE REVIEW}

\section{Homecoming or mudik}

The definition of homecoming in the Indonesian General Dictionary (Kemdikbud, 2020) is defined as sailing or going to udik (upstream, inland) and udik itself means village or hamlet (versus city). Accordingly, there are several alternative definitions of homecoming based on KBBI (Kemdikbud, 2020), as follows:
1. Sailing upstream of the river
2. Sailing inland
3. Go to the interior
4. Go to the village
5. Go to the hamlet

All of the above definitions basically provide meaning go to a place that is the opposite of the city. City based on KBBI (Kemdikbud,2020) has a meaning as a population concentration area with high density as well as modern facilities and most of the population work other than in agriculture sector. With this understanding, every activity goes to the remote area or village or hamlet is known as homecoming or mudik.

Indonesian people have associated homecoming with holiday in a particular religion. Homecoming has become a tradition in Indonesia especially in welcoming the Eid Al-Fitr (Lebaran/Hari Raya). The meaning of going home for some society is an activity that has the following characters:

1. Going just before Hari Raya

2. Go to the place of birth, the place where parents lived

3. Depart with new clothes and souvenirs/ hampers

4. Bring certain foods that are served during homecoming

5. Carry out certain activities during homecoming, namely visiting relatives, neighbors, friends, and/or recreation.

6. Discuss certain topics during homecoming 
Homecoming which is always associated with Eid Al-Fitr (Lebaran), has happened since a long time ago. In general, homecoming occurs from big cities to small towns or from a town to a village. This happened because originally the villagers move to a city to get a job that is widely available in the city (urbanization), for example Jakarta which is one of the big cities in Indonesia. People from smaller cities and/or villages come to Jakarta to find work and then stay on. Most of them are people who routinely revisit to their original family places every month, but they still call it 'go home' not homecoming. The term homecoming or mudik is always associated with Idul Fitri (Lebaran).

The destination of going home is various. The main destination of homecoming is a place where the parents are, if the parents are still alive. However, if the parents have been passed away, the destination is to a place where there is a family who acts as parents or elders. But, if there has been no elders anymore then the purpose of going home is for recreation with nostalgic memories. Activities carried out by travelers during homecoming apart from staying in touch are doing recreation with family, relatives and friends. Thus, all congestion on roads between cities and congestion in recreation areas besome common things during homecoming period.

Homecoming is also used as a time for pilgrimage. Eid is a momentum that is considered appropriate for pilgrimage, because Eid has religious aspects. It is religiously acceptable if Eid is the right time for pilgrimage.

\section{Myth and Simulacra}

According to Barthes (1972b) myth is not defined by the object of its message, but by the way in which the message is expressed: there are formal boundaries to myth, there are no substantial boundaries. Every object in the world can switch from a closed and silent existence to an open verbal state of use by society. No myth is eternal because of human history which transforms reality into that type of speech and then governs the life and death of mystical language. Mythology can only have a historical foundation, because myth is a kind of speech that history chooses, myths are unlikely to develop from essence. The type of speech as a message is not limited to the spoken form but they can also be written or illustrative forms. Myth according to Barthes (1972b) cannot be defined by the object or material, because any material can be equipped with meaning at will.

The myth in this study is different from the myth according to Eliade (1958) who put myth not as a type of speech but as something associated with a belief or belief. However there is similarity of views regarding the position of myth, that it is a necessity to face historical humans who consciously and voluntarily create history with humans from traditional civilization.

From a semiological perspective, myth is a sign system, within it there is a kind of existence which is ever present, the point of its factoring being formed by the appearance of meaning. With the advancement of human civilization, meaning can change so that myths also have evolution, are built, perpetuated, destroyed and rebuilt.

Associated with Baudrillard's (Lane, 2000) thinking that there are three stages (order) of appearance, and then the myths in the three orders will be different. If at this time the world is in the third stage or simulation where something produces its own reality which is formed without being based on in the slightest part of the reality of the world, then myth is a perpetuation the meaning of connotation as a battle of the image of something that is constructed by the individual self. The image that is perceived from the outside is selected and then internalized within the individual and presented as something new that comes out of oneself individuals who are not aware of the relationship to the image that had existed in his consciousness. Thus, on each order of appearance, the myth will have different characteristics and is the result of image confrontations based on the characteristics of each order the apparition. 
According to Baudrillard (1994a) there are 3 (three orders) of simulacras as the following:

1. Counterfeit; in this order the simulacra is natural, contained in image, on imitation that is harmonious, optimistic, and aims to restore something natural;

2. Production; in this order simulacra is productive; it is in energy or strength. Manifest as a result of production in the entire production system, and aims to continue globalization and expansion, liberation without limit of energy;

3. Simulations; in this order simulacras are simulations, contained in information. It is a model, operates totally, hyper reality and aims for total control.

\section{RESEARCH METHOD}

The research conducted is normative research or study literature, using a variety of literature that discusses regarding myths, simulacras and simulations. The research method used is a semiotic approach. This semiotic approach is used with based on the idea that the notion of myth in this study using the understanding of myth according to Barthes's view of the myth as semiological system of the second order (simulacra).

Furthermore, because the understanding of simulacras and simulations is using the meaning of Baudrillard, the Baudrillard's also influences the research method being carried out. Homecoming validation as a myth will be carried out using the interview method.

\section{DISCUSSION}

\section{Homecoming as myth}

Myth based on the view of Barthes (1976a) is a type of talk. A text is not a line of displaying words single theological meaning (message of the author or God) but a multi-dimensional space in which a wide variety of writings, none of which original, jumbled up and clashed. Text is a network quotes taken from many countless cultural centers (Barthes, 1972b).

Homecoming as a myth has developed towards content, and both occur in human cognition. Expressions or disclosures Homecoming experienced development towards content or concept, namely:

1. Buy new things: clothes, food, toys, crafts, tools communications and new electronic tools

2. Drive a new vehicle

3. Talking about certain topics during homecoming

Homecoming as an expression, thus experiencing development to the secondary system has connotative meaning. The meaning of this connotation perpetuated by the community and occurs every year so that it becomes a myth in society. Homecoming experiences the development of meaning into connotative meaning, not only at the stage of cognition in humans but also affecting behavior. The meaning of homecoming does not stop at the stage meaning, but individuals have the meaning of the homecoming connotation as actual behavior and actions. Homecoming which was originally interpreted as returning home has experienced development from going only to the village, in the sense that the area has less modern characteristics than cities. Homecoming can actualy just go to a larger city or even to a more developed country.

Furthermore, homecoming which was originally interpreted as going to the village, experiences a development of meaning into going to a place of birth or a place previously raised or a place where old people residing or settling. Besides, homecoming becomes the activity of buying and carrying and using new things, for example new clothes, toys, food, crafts, electronic goods, new vehicles and exchange for change.

The meaning of homecoming that has gone through enlargement has a significant emotion effect and risk consideration. The effect on emotions such as delighted emotions when individuals are able to carry out homecoming. On the other hand, the meaning of going home can also arouse negative emotions in the form of 
sadness when individuals are unable to carry out appropriate homecoming activities. Thus, the meaning of homecoming has developed not only on the stage of cognition, but has arrived at the stage of affection and behavior. The meaning of homecoming that develops and affects behavior shifts from spatial activities towards social society interaction in a routine activity, namely "mudik".

\section{Baudrillard's Simulacra}

In this study, the simulacra concept is from the perspective of Baudrillard (1994b). It is expected to be an adequate and organic situate for the meaning of homecoming which has undergone elaboration. According to Baudrillard (1994a) there are 3 (three orders) of simulacras, namely counterfeit (natural), production, and simulations. Simulation is no longer a zone, rather a referential form or substance. It is a creation through models from something real, which is without origin or existence; it is a hyperreal. Territory no longer precedes the map, not really defend it. The map precedes teritory-precession of simulacra (Baudrillard, 1983).

Based on those three types of simulacras, the meaning of homecoming that experiences development can have three spaces, as an imitation, as a production and as a simulation, and thus, delivers to hyper reality. The shift of the meaning are in the three areas of the Baudrillard's simulacra (1994b).

For the first motion area or first order of simulacra, namely as imitation, the development of initial meaning of homecoming as returning to a village turns out to be the myth of revisiting not only to a less modern city. It is still defined as homecoming when going to a larger city or to a more developed country. Travelers who carry out activities or behave in this way, still consciusly interpret these activities as homecoming because the destination is the place of birth or place when raised or where the parents live.

For the second motion area or second order simulacra, namely as production, the development of initial meaning of homecoming as returning to a village turns out to be the myth of buying various goods or consumption, for example clothes, toys, food, electronics and vehicles. The initial meaning of home coming as returning to the village has converted a myth of purchasing of various goods.

For the third space or third order simulacra, namely simulation, homecoming which initially means returning to a village, really doesn't have nostalgic representation of the past any more, but travel to a tourism spot. At this stage home coming becomes emotionally and urgently influence the potential home comers to do activities that are completely different to the intial meaning of home coming. At this stage, the travelers has no longer consuming goods but rather utilizing signs, by making homecoming to legitimate social status and initiate delighted emotions.

\section{Home Coming Myth in Simulacra}

Urbanization deeply descends the existence of urbanites in an other various existences in a big city. Apart from that, social legitimacy for the majority of urbanites it is also low and even almost not felt. An home coming to a hometown is only a camouflage of enthusiasm to obtain social legitimacy and demonstrate the existence of urbanites. Thus, home coming is a means for urban people to show an achieved success to their native place. Homecoming has become a means for travelers to come back rediscovering his confidence as a person and for getting respect or social legitimacy.

This respect or social legitimacy is usually explained because of positive word of mouth for being an urbanity. Someone who move to a city is usually considered to be successful in achieving (feel) success, and then willing to loyally come back to the city. Zethaml, Berry, \& Parasuraman (1996) and Ganesh, Arnold, \& Reynolds (2000) found the indicators of loyalty including favorable behavioral intentions consisting of positive word of mouth (WOM) and unfavorable behavioral intentions consist of switching behavior and complaining behavior. 
Besides, positive word of mouth of urbanities can be in form of recommending to friends, telling positive things and encouraging others to move out to urban area because of the satisfaction of its social legitimacy. In addition, satisfaction and WOM has a positive relationship (Leonnard et al, 2013; Leonnard et al, 2014). WOM is a state in which satisfied consumers spread positive impression about their experience when consuming products or services directly or as a result of actual performances that exceeds their expectations (Arndt, 1967; Wien \& Olsen, 2017). In this research, "the product" may refer to urbanization and its social existence related.

As a form of social existence, homecoming has appeared and changed into various forms as the simulacra order, where Baudrillard (1994a) states that there are three orders of appearances, namely counterfeit (natural), production, and simulations. Homecoming is a myth, where the meaning of home coming has revolved into various connotative meanings perpetuated such as new clothes, recreation, and so on. Home coming interpretarion dynamically modifies in simulacra, which present in the sense of real return because it does not mean going home to a place of born or raised, but somewhere else that is has the same character as the place when the travelers were born or raised. Homecoming has even become hyperreal, when it no longer refers to returning to a place where you have lived previously.

\section{CONCLUSION}

Homecoming can be understood as a need for social existence and human legitimacy. Regrowth of existence in a society carrying out homecoming can be done by understanding the characteristics of the homecoming perceived by society. By understanding the homecoming character perceived by society, the need for existence through "mudik" can put into other activities so that people carry out to a more rational homecoming regularly.

Because the research is in the from of literature and qualitative study, it is necessary to carry out further research on public perceptions regarding homecoming by considering cultural or ethnic factors, and also favorable behavioral intentions consisting of positive word of mouth (WOM).

The development of activities or means of the existence of travelers through understanding the character of homecoming needs to be performed as a solution to reduce irrationality homecoming indication where safety becomes an overlooked factor in comparison to the needs for social existence and legitimacy.

\section{REFERE N C E S}

Arndt, J. (1967). Role of Product-related Conversations in The Diffusion of a New Product. Journal of marketing Research. Vol. 4 (3): 291-295.

Barthes, Roland. (1972a). Membedah Mitos-mitos Budaya Massa : Semiotika atau Sosiologi Tanda, Simbol dan Representasi. Yogyakarta: Jalasutra.

Barthes, Roland. (1972b). A Roland Barthes Reader. London: Vintage.

Baudrillard, Jean. (1983). Simulations. USA: Semiotext(e)

Baudrillard, Jean. (1994a). Simulacra and Simulation. The University of Michigan.

Baudrillard, Jean. (1994b). Simulacra and Simulations : Selected Writings. Stanford University Press.

CNN Indonesia. (2019). Kecelakaan Lalu Lintas 2019 Menurun 65 Persen. From https:// www.cnnindonesia.com/nasional/20190611003206-20-402241/kecelakaan-lalu-lintas-lebaran2019-menurun-65-persen

Eliade, Mircea. (1958). Pattern in Comparative Religion. London and New York: Sheed and Ward. 
Ganesh, J., Arnold, M. J., Reynolds, K. E. (2000). Understanding the customer base of service providers: an examination of the differences between switchers and stayers. Journal of marketing, 64(3), 65-87.

[Kemdikbud] Kementerian Pendidikan dan Kebudayaan. 2020. Kamus Besar Bahasa Indonesia

Lane, Richard J. (2000). Jean Baudrillard. London and New York: Routledge

Leonnard., Daryanto, H. K., Sukandar, D., \& Yusuf, E. Z. (2013). The Loyalty Model of Private University Student, Study Case: Stikom London School of Public Relation. International Journal of Information Technology and Business Management. Vol. 20(1): 91-100.

Leonnard, L., Daryanto, H. K., Sukandar, D., Yusuf, E. Z. (2014). The Loyalty Model of Private University Student. International Research Journal of Business Studies, 7(1).

Wien, A. H., \& Olsen, S. O. (2017). Producing Word of Mouth-a Matter of Self-Confidence? Investigating a Dual Effect of Consumer Self-confidence on WOM. Australasian Marketing Journal (AMJ). Vol. 25(1): 38-45.

Zeithaml, V. A., Parasuraman, A., Malhotra, A. (2002). Service quality delivery through web sites: a critical review of extant knowledge. Journal of the academy of marketing science, 30(4), 362-375. 